\title{
Long-term Efficacy of Oil-adjuvant Influenza Vaccine in an Industrial Population
}

\author{
R. W. HOWELL \\ From the Authority Health and Safety Branch, U.K. Atomic Energy Authority, Harwell, Berks
}

The mild influenza epidemic of mixed A and B strains early in 1966 provided an opportunity to assess the efficacy of an oil-adjuvant influenza vaccine which had been administered more than two years earlier to I,34I volunteers at two U.K. Atomic Energy Authority establishments. At the $5 \%$ confidence level, a statistically significant reduction in sickness absence due to influenza was found in this vaccinated group when compared with a control group of 918 employees. This trend was observed at both establishments. Some confirmation was thus obtained of serological predictions that protection would last two to three years or longer after inoculation. There was some indication that the vaccine might be more effective in older workers. This trial suggests the need for more long-term evaluation of oil-adjuvant influenza vaccines.

Hobson, Lane, Beare, and Chivers (1964) found high haemagglutination-inhibiting (H.I.) antibody titres in the sera of almost half their volunteers who had been inoculated with an oil-adjuvant influenza vaccine more than two years previously. The antibody titres which were found suggest that if artificially induced antibodies are as effective as naturally acquired antibodies (a supposition by no means proven), the clinical protection offered by such vaccines may well extend to three years or longer.

Davenport, Hennessy, and Bell (I962) pointed out that, with adjuvant vaccines, antibody levels of from a quarter to a half of the maximum attained have been found eight to nine years after inoculation. Himmelweit (1963) suggested that, because of the efficacy of these vaccines, inoculation of a substantial part of the general population every three to five years might be sufficient to build up a herd immunity against prevalent viruses. However, such suggestions are based largely on serological evidence, and there has been no general confirmation in this country based on large-scale clinical trials.

Howell and Stott (1964) reported a trial of oiladjuvant vaccine in 1,679 employees at two U.K. Atomic Energy Establishments (Springfields and Dounreay). The occurrence of a mild influenza epidemic of mixed A and B strains in the early part of 1966, more than two years after the inoculation of these employees, suggested that an attempt should be made to discover whether the vaccinated group

Received for publication June I5, 1966. fared better than the control group when judged by certified sickness absence experience.

Previous experience and enquiry had shown that influenza vaccine had not been given to any Authority employees at these two establishments by outside medical sources, and it was reasonable to assume that the vaccination state of the two groups had remained unchanged since 1963 . Indeed, in the rural atmosphere of Dounreay any outside inoculation programme would not have gone unremarked.

\section{Methods}

Original Trial An oil-adjuvant vaccine, ${ }^{1}$ incorporating the strains $A / \operatorname{Sing} / \mathbf{I} / 57 / \mathrm{Col}$, A/Eng/r/6I, B/Eng/939/59, and B/Tai/4/62, was offered to all staff at the two establishments. A single dose of $0.25 \mathrm{ml}$. was administered from a disposable syringe intramuscularly into a deltoid muscle.

Control groups were randomly selected at each establishment from non-inoculated staff using a standard pack of Rand random cards. Since volunteer groups are obviously self-selecting, they may well differ in important characteristics from the population from which they are drawn. It was therefore necessary to ensure the comparability of the two groups before assessing the protective effect of inoculation. The groups were found to be similar in composition when analysed by age, sex, work status, and, most important, previous respiratory sickness absence.
${ }^{1}$ Admune, Evans Medical Ltd. 
Present Composition of the Groups By the end of April 1966, when the influenza epidemic had subsided, natural staff wastage had reduced the numbers exposed in both the vaccinated and control groups. This natural wastage was largely caused by staff joining other employers, transfers to other Authority establishments, and by age retirements. There were two deaths in the vaccinated group and two in the control group. There had been only one retirement due to respiratory disease and this was in the control group. Of the original vaccinated group $79.9 \%$ remained, as did $82 \cdot 1 \%$ of the control group. As the standard error of the difference in these percentages is $\mathrm{I} \cdot 5 \%$, this variation was probably a chance one. Similarly, the two groups were still comparable when analysed by age, sex, and work status (Tables I and II).
Although the two groups appeared comparable when judged by age, sex, and work status, it was thought prudent to confirm that they were still experiencing similar respiratory sickness absence. Respiratory sickness absence for 1965 for the two groups was abstracted from routine records. Since it could be contended that the vaccinated group had a potential advantage in respect of influenzal absences (although these establishments were remarkably free of influenza in 1965) such absences have been excluded.

Table III shows that there were no statistically significant differences between the groups in 1965.

Diagnosis and Classification Diagnosis and classification were carried out as in the previous paper, with the diagnoses classified under the Inter-

TABLE I

Vaccinated and Control Group Numbers by Age, Sex, and Work Status (SPRINGFIELDS AND DOUNREAY COMBINED)

\begin{tabular}{|c|c|c|c|c|c|c|c|c|}
\hline & & & & \multicolumn{2}{|c|}{$\begin{array}{c}\text { Vaccinated } \\
\text { Group }\end{array}$} & \multicolumn{2}{|c|}{$\begin{array}{c}\text { Control } \\
\text { Group }\end{array}$} & \multirow{2}{*}{$\begin{array}{c}\text { Standard Error } \\
\text { of Differences } \\
(\%)\end{array}$} \\
\hline & & & & No. & $(\%)$ & No. & $(\%)$ & \\
\hline \multicolumn{4}{|c|}{ Male non-manual workers } & & & & & \\
\hline I 5-44 years & .. & $\cdots$ & .. & 340 & $77 \cdot 8$ & 230 & $78 \cdot 8$ & $3 \cdot 4$ \\
\hline 45 and over & $\cdots$ & $\cdots$ & $\cdots$ & 97 & $22 \cdot 2$ & 62 & $2 I \cdot I$ & \\
\hline Total & $\cdots$ & $\cdots$ & $\cdots$ & 437 & 100 & 292 & IOO & \\
\hline \multicolumn{4}{|c|}{ Male manual workers } & & & & & \\
\hline I5-44 years & . & .. & .. & 535 & $62 \cdot 9$ & 351 & $60 \cdot 0$ & $2 \cdot 6$ \\
\hline 45 and over & $\cdots$ & $\cdots$ & $\cdots$ & 315 & $37 \cdot 1$ & 234 & $40 \cdot 0$ & \\
\hline Total & . & $\ldots$ & $\cdots$ & 850 & 100 & 585 & 100 & \\
\hline \multicolumn{4}{|c|}{ Female non-manual workers } & & & & & \\
\hline I5-44 years & . & . & . & $5 \mathrm{I}$ & $94 \cdot 4$ & 37 & $90 \cdot 2$ & $5 \cdot 6$ \\
\hline 45 and over & $\cdots$ & $\cdots$ & $\cdots$ & 3 & $5 \cdot 6$ & 4 & $9 \cdot 8$ & \\
\hline Total & $\cdots$ & $\cdots$ & . & 54 & 100 & $4 I$ & 100 & \\
\hline
\end{tabular}

TABLE II

Group Proportions by SEx aNd Work Status

\begin{tabular}{|c|c|c|c|c|c|c|}
\hline & & \multicolumn{2}{|c|}{$\begin{array}{c}\text { Vaccinated } \\
\text { Group }\end{array}$} & \multicolumn{2}{|c|}{$\begin{array}{c}\text { Control } \\
\text { Group }\end{array}$} & \multirow{2}{*}{$\begin{array}{c}\text { Standard Error } \\
\text { of Differences } \\
(\%)\end{array}$} \\
\hline & & No. & $(\%)$ & No. & $(\%)$ & \\
\hline $\begin{array}{l}\text { Male non-manual workers .. } \\
\text { Male manual workers } \\
\text { Female non-manual workers }\end{array}$ & $\begin{array}{l}\cdots \\
\cdots \\
\cdots\end{array}$ & $\begin{array}{r}437 \\
850 \\
54\end{array}$ & $\begin{array}{r}32 \cdot 6 \\
63 \cdot 4 \\
4 \cdot 0\end{array}$ & $\begin{array}{r}292 \\
585 \\
41\end{array}$ & $\begin{array}{r}31 \cdot 8 \\
63 \cdot 7 \\
4 \cdot 5\end{array}$ & $\begin{array}{l}2 \cdot 0 \\
2 \cdot 0 \\
0 \cdot 9\end{array}$ \\
\hline Total & . & I,34I & 100 & 918 & 100 & \\
\hline
\end{tabular}


TABLE III

Proportion of Employees With Respiratory ABSENCES (OTHER THAN INFLUENZA) IN 1965

\begin{tabular}{|c|c|c|c|}
\hline Disease Grouping & $\begin{array}{l}\text { Vac- } \\
\text { cinated } \\
\text { Group } \\
(\%)\end{array}$ & $\begin{array}{l}\text { Control } \\
\text { Group } \\
(\%)\end{array}$ & $\begin{array}{c}\text { Standard Error } \\
\text { of Differences } \\
(\%)\end{array}$ \\
\hline $\begin{array}{l}\text { Acute upper respiratory } \\
\text { tract infection }\end{array}$ & 12.5 & $14 \cdot 6$ & 1.5 \\
\hline $\begin{array}{ccc}\text { Bronchitis } & . & . . \\
\text { All other respiratory } \\
\text { disease (except in- } \\
\text { fluenza) } & . . & . .\end{array}$ & $4 \cdot 2$ & $3 \cdot 7$ & 0.8 \\
\hline $\begin{array}{c}\text { Any respiratory disease } \\
\text { (except influenza) }\end{array}$ & $17 \cdot 7$ & $19 \cdot 6$ & $\mathbf{I} \cdot 7$ \\
\hline
\end{tabular}

TABLE IV

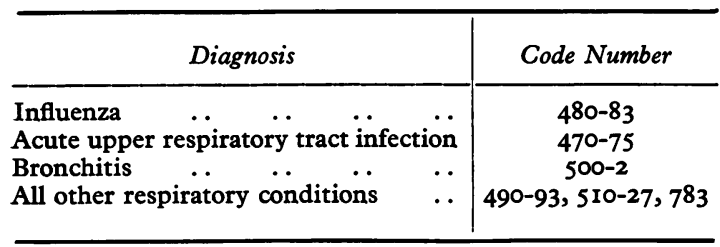

national Statistical Classification of the World Health Organization (Table IV).

\section{Results}

All certified sickness absence arising from respiratory causes during the period January $I$ to April 30, I966 was abstracted from routine records maintained on magnetic tape. All episodes for the two groups were included regardless of the duration of absence; the proportion of absences of less than four days' duration was $I \cdot 9 \%$ in each group. Only in the influenza group was there a significant difference at the $5 \%$ confidence level between the vaccinated and control groups (Table V), and this was sufficient to give the vaccinated group a significant advantage when all respiratory episodes were combined (Table V). The totals shown in Table V do not equal the sum of the disease groupings, since the groups are not mutually exclusive. People who appear only once in the total may be included in more than one respiratory group. This trend in favour of the vaccinated group was apparent at both Springfields and Dounreay, although the numbers at risk at Springfields yielded results which were rather small for formal tests of significance; for this reason separate tables are not given. The protection rate of about $30 \%$ was almost exactly that found in an earlier trial in the Atomic Energy Authority (Meichen, Rogan, and Howell, 1962) in an epidemic year. On that occasion, the vaccine was a saline one which had been administered shortly before the outbreak. Another finding common to the 1962 report was that the vaccine appeared to be more effective in the older workers (Table VI) although the difference was not statistically significant.

\section{TABLE V}

Proportion of EMployees With Respiratory ABsences BETWEEN JANUARY I AND APRIL 30, 1966

\begin{tabular}{|c|c|c|c|}
\hline Disease Grouping & $\begin{array}{c}\text { Vac- } \\
\text { cinated } \\
\text { Group } \\
(\%)\end{array}$ & $\begin{array}{c}\text { Control } \\
\text { Group } \\
(\%)\end{array}$ & $\begin{array}{c}\text { Standard Error } \\
\text { of Differences } \\
(\%)\end{array}$ \\
\hline $\begin{array}{ccr}\begin{array}{c}\text { Upper respiratory } \\
\text { infection }\end{array} & . & . . \\
\text { Influenza } & . & . . \\
\text { Bronchitis } & . & . . \\
\text { All other } & \text { respiratory } \\
\text { disease } & . & . .\end{array}$ & $\begin{array}{r}4 \cdot 8 \\
\mathrm{II} \cdot 4 \\
\mathrm{I} \cdot 7 \\
\mathrm{I} \cdot 5\end{array}$ & $\begin{array}{r}5 \cdot 2 \\
14 \cdot 9 \\
1 \cdot 1 \\
1 \cdot 0\end{array}$ & $\begin{array}{l}0.9 \\
1.5^{1} \\
0.5 \\
0.5\end{array}$ \\
\hline Any respiratory disease & $18 \cdot 3$ & $2 \mathrm{r} \cdot 8$ & $\mathrm{r} \cdot \mathbf{7}^{1}$ \\
\hline
\end{tabular}

${ }^{1}$ Significant at the $5 \%$ confidence level

\section{TABLE VI}

Proportion of Employees, by Age Groupings, with ABSENCE DUE TO INFLUENZA BETWEEN JANUARYI AND APRIL 30, 1966

\begin{tabular}{c|c|c|c}
\hline Age Group & $\begin{array}{c}\text { Vaccinated } \\
\text { Group } \\
(\%)\end{array}$ & $\begin{array}{c}\text { Control } \\
\text { Group } \\
(\%)\end{array}$ & $\begin{array}{c}\text { Standard Error } \\
\text { of Differences } \\
(\%)\end{array}$ \\
\hline 15-44 years .. & 12.5 & 15.7 & 1.8 \\
45 and over .. & 8.7 & 13.3 & 2.4 \\
\hline
\end{tabular}

The data from previous tables expressed in the conventional industrial manner (Table VII) showed an improvement for the influenza disease group in the vaccinated staff but little real difference otherwise. Once sickness absence had occurred no real effect on the length of absence could be attributed to the vaccine, though it is fair to say that the vaccinated group showed slightly better figures (Table VII). The variation in the length of absence in the 'other respiratory episodes' group is possibly a reflection of the small numbers involved.

\section{Discussion}

Many recent reports (Cook, 1965; Howell and Mackenzie, 1964; Howell and Stott, 1964; Meichen 
TABLE VII

SickNeSS ABSENCE Rates by Respiratory Groupings

\begin{tabular}{|c|c|c|c|c|c|c|c|}
\hline \multirow[b]{2}{*}{ Disease Group } & & \multicolumn{3}{|c|}{ Vaciinated Group } & \multicolumn{3}{|c|}{ Control Group } \\
\hline & & $\begin{array}{c}\text { Days Lost } \\
\text { per 100 } \\
\text { Workers }\end{array}$ & $\begin{array}{l}\text { No. of } \\
\text { Episodes } \\
\text { per Ioo } \\
\text { Workers }\end{array}$ & $\begin{array}{c}\text { Average } \\
\text { Length of } \\
\text { Absence } \\
\text { (days) }\end{array}$ & $\begin{array}{l}\text { Days Lost } \\
\text { per Ioo } \\
\text { Workers }\end{array}$ & $\begin{array}{l}\text { No. of } \\
\text { Episodes } \\
\text { per Ioo } \\
\text { Workers }\end{array}$ & $\begin{array}{c}\text { Average } \\
\text { Length of } \\
\text { Absence } \\
\text { (days) }\end{array}$ \\
\hline $\begin{array}{l}\text { Upper respiratory tr } \\
\text { infection }\end{array}$ & $\begin{array}{l}\text { ct } \\
\cdots \\
\cdots \\
\cdots \\
\cdots\end{array}$ & $\begin{array}{r}52 \\
150 \\
29 \\
32\end{array}$ & $\begin{array}{r}4 \cdot 9 \\
11 \cdot 9 \\
1 \cdot 7 \\
1 \cdot 6\end{array}$ & $\begin{array}{l}10 \cdot 6 \\
12 \cdot 7 \\
16 \cdot 7 \\
20 \cdot 4\end{array}$ & $\begin{array}{r}60 \\
224 \\
19 \\
10\end{array}$ & $\begin{array}{r}5 \cdot 4 \\
15 \cdot 5 \\
1 \cdot 1 \\
1 \cdot 0\end{array}$ & $\begin{array}{r}\text { II. I } \\
14.5 \\
17 \cdot 8 \\
9 \cdot 8\end{array}$ \\
\hline All episodes & .. & 263 & $20 \cdot I$ & $13 \cdot 1$ & 313 & $23 \cdot 0$ & $13 \cdot 6$ \\
\hline
\end{tabular}

et al., 1962; Richardson and Kilpatrick, 1964) from industrial populations have found the value of influenza vaccine to be unproven, partly because the protection obtained has generally been regarded as unsatisfactory, especially in non-epidemic years, partly because of the frequency of adverse reactions to the inoculation, and partly because of declining enthusiasm among employees. Additionally, the cost of an annual programme is sizeable in terms of staff time and money.

In this trial the vaccinated group showed significantly better absence rates (at the $5 \%$ level of confidence) than the control group for all respiratory diseases. In the disease groupings significance was achieved only in the influenza group. However, as in the previous trial (Meichen et al., 1962), the incidence of upper respiratory tract infection was slightly less in the inoculated group. This is also in line with the finding of the Medical Research Council (Stuart-Harris, 1965) that the incidence of febrile colds was reduced in those who had received influenza $B$ vaccine. The clinical diagnosis of milder influenza B was more likely to be described as a febrile cold than influenza A.

Since this study related to four months only, quite clearly these vaccines are not likely to show great reductions in sickness absence over the whole year, for the inoculated group no longer fared significantly better when non-respiratory sickness absence was included. Greatly improved rates must wait, perhaps, until effective and easy control can also be obtained over respiratory adenoviruses. On the other hand, there may be great advantages to the employer if he can avoid production and other bottlenecks caused by the absence of large numbers of staff at the same time; if there is any demand for this service by employees, a suitable programme may aid industrial relationships. If the vaccine can be established as being painless and effective, such a programme may be attractive to the employee.

The difficulties inherent in a trial of this nature are readily apparent, and it is not easy to be sure, as a result of a single investigation, whether the results fully parallel previous serological predictions. The possibility that antibody levels might have been affected by intermittent influenza between the time of vaccination in 1963 and the present assessment cannot be entirely excluded. However, the incidence of clinical influenza in those years was low (approximately $4 \%$ ) and this possibility therefore seems unlikely. Furthermore, such natural reinforcement (boosting) might have been expected to narrow the difference in immune status between the two groups.

Adjuvant vaccines have at present been withdrawn in this country because of nodule formation in a very small proportion of those inoculated. As these vaccines, perhaps in an improved form, may be back on the market for large-scale prophylaxis, further trials to evaluate the protective period are of some importance.

I am grateful to Dr. D. Hobson, University of Liverpool, for criticism of the manuscript, and to Dr. T. Graham, Springfields, and Dr. S. M. B. Hill, Dounreay, for access to their records.

\section{REFERENCES}

Cook, P. B. (1965). Brit. F. industr. Med., 22, 217. Davenport, F. M., Hennessy, A. V., and Bell, J. A. (1962). Milit. Med., 127, 95.

Himmelweit, F. (1963). Brit. F. clin. Pract., 17, 661.

Hobson, D., Lane, C. A., Beare, A. S., and Chivers, C. P. (1964). Brit. med. F., 2, 27 I. 
Howell, R. W., and Mackenzie, A. B. (1964). Brit.F. industr. Richardson, I. M., and Kilpatrick, S. J. (1964). Med. Offr, Med., 2I, 265.

$\longrightarrow$, and Stott, A. N. B. (1964). Ibid., 21, 259.

Meichen, F. W., Rogan, E., and Howell, R. W. (I962). Ibid., I9, 203.

Stuart-Harris, C. H. (1965). Influenza and Other Virus Infections of the Respiratory Tract, 2nd ed., p. 212. Arnold, London. 